\title{
The development of Typhoid vaccine in Indonesia
}

\author{
Cyrus H. Simanjuntak
}

\begin{abstract}
Abstrak
Deman tifoid di Indonesia sangat endemis dengan insidens dari 360 kasus (di pedesaan) dan mencapai 810 kasus (di perkotaan) per 100.000 populasi pertahun. Vaksin kuman utuh konvensional yang diberikan secara parenteral sudah lama dikenal dan digunakan di Indonesia. Sejak tahun 1960-an, program imunisasi menggunakan vaksin tersebut untuk bayi-bayi dihentikan karena efek sampingnya. Sejak saat itu insidens demam tifoid meningkat. Saat ini terdapat dua vaksin untuk demam tifoid yang relatif baru dan beredar di Indonesia, yaitu vaksin Ty2 la (Vivotiv(B), yang merupakan vaksin oral yang dilemahkan dalam formulasi kapsul enteric coated yang memiliki efisiensi 42-53\%, dan vaksin parenteral Vi polisakharida kapsul (TyphimVi®) yang mengandung antigen Vi S. typhi yang dimurnikan dan memiliki efisiensi $64-80 \%$.
\end{abstract}

\begin{abstract}
Typhoid fever is highly endemic in Indonesia with the incidence range from 360 cases (semirural area) to 810 cases (urban area) per 100,000 population per year. The conventional whole cell vaccine which is parenteral, has long been known and used in Indonesia. Since 1960's immunization with this conventional vaccine was terminated from the vaccine program for infants, due to its annoying and inconvenient side effects. Since that time the incidence of typhoid fever has been observed to be increasing. At present, there are 2 kinds of relatively new vaccine against typhoid fever that have been licensed and circulating in Indonesia. The first one is Ty21a (Vivotiv (B), the attenuated oral vaccine with the efficacy of $42-53 \%$ for the enteric coated capsule formulation. The second is the parenteral ViCapsular polysaccharide vaccine (TyphimVi(B), the purified Vi-antigen of Salmonella typhi with the efficacy of 64-80\%.
\end{abstract}

\section{Introduction}

Typhoid fever is still highly endemic in Indonesia. Nevertheless, there are very few population based epidemiological study of typhoid fever in Indonesia. There are only 2 epidemiological studies that have been conducted so far. First, was the epidemiological study at a semi urban area, Paseh District, which is about $10 \mathrm{~km}$ south of Bandung that was carried out in 1986. The incidence of typhoid fever in this area was 350 cases per 100,000 population per yearl. The second study was the epidemiological study during the efficacy trial of oral typhoid vaccine at Plaju, South Sumatera in 1986-1990. The incidence of typhoid fever in this area was 810 cases per 100,000 population per year ${ }^{2}$.

The collected data by Directorate general of CDC \& ESH, of hospitalized typhoid fever cases from all hospitals in the country revealed the increased number of reported typhoid cases from 19,596 in 1981 to 26,596 in 1986. On the contrary, the CFR of typhoid fever has decreased from $3.4 \%$ in 1981 to $2 \%$ in 1986. This is due to the improvement of health facili-

National Institute of Health Research and Development Jakarta, Indonesia ties and services ${ }^{3}$ in the country. The reported incidence of typhoid fever from health centers and hospitals has also increased from 9.2 cases $/ 10,000$ pop./year to 15.4 cases $/ 10,000$ pop./year 4 .

The continuous increase of the incidence of typhoid fever is the reflection of discontinuation of conventional parenteral vaccination program in 1960's. Before that period the conventional whole cell vaccine that has long been known was used in the program to immunize infants as chotypa (Cholera, typhoid and paratyphoid in one syringe), together with DPT and polio vaccines. The termination of this vaccine was due to the high incidence of inconvenient side-effects of the vaccine.

After more than 15 years period without any National immunization program against typhoid fever, at present we have 2 potentially better vaccines against typhoid fever, ie. oral vaccine, Ty21a and parenteral ViCPS vaccines.

\section{Oral typhoid vaccine, Ty21a}

The attenuated oral typhoid vaccine, Ty21a, was evaluated for its efficacy and side effects in Indonesia at Pertamina complex, Plaju, South Sumatera in 1986-1990. Two formulations of Ty21a vaccine were evaluated: the enteric coated capsule and the sachet 
of lyophilised vaccine powder. The lyophilised vaccine powder was freshly reconstituted with phosphate buffer solution at the time of vaccination. After 30 months of follow up, it was found that the protective efficacies of the attenuated enteric coated and the liquid formulation vaccine are $42 \%$ and $53 \%$, respectively in the area where the incidence of typhoid fever is $810 / 100,000$ pop./year ${ }^{1}$. Although no major side-effect was noted, the overall incidence of sideeffects in comparison to placebo was greater in the vaccine group.

The above results revealed that under condition of intense transmission, Ty21a vaccine protects about $50 \%$ of the population against typhoid fever. The duration of protective efficacy of Ty 21 a vaccine in Santiago, Chile study is at least 6 years.

In the condition of low transmission such as Alexandria, Egypt where the typhoid incidence was only $49 / 100,000$ pop./year the protective efficacy of the vaccine was $96 \% 5$ for school age children. While in Santiago, Chile an area with moderate transmission of typhoid fever, with the incidence of $142 / 100,000$ pop./year, the protective efficacy of the enteric coated formulation vaccine was $67 \% 6$.

The duration of protective efficacy of this vaccine is 6 years based on the continuous follow up from Santiago field trials ${ }^{7}$. The optimal dose for the vaccine is 3 doses with the time duration between doses is one day.

\section{Parenteral Vi-CPS vaccine}

$\mathrm{Vi-Capsular}$ polysaccharide ( $\mathrm{Vi}-\mathrm{CPS}$ ) vaccine is a promising potential parenteral single dose vaccine that has been evaluated not only elsewhere, but also in Indonesia. This vaccine is a purified Vi-antigen from $S$. typhi strain. The protective efficacy (phase 3 ) as well as its side effects has been evaluated in South Africa and Nepal8,9. The protective efficacy of this vaccine in South Africa was $64-81 \%$ and the incidence of typhoid fever in that area was $470 / 100,000$ pop./year. In Nepal the protective efficacy of Vi-CPS was $72-81 \%$ with the reported incidence of typhoid fever was $1,620 / 100,000$ pop./year. The typhoid fever incidence in these two areas are quite comparable to those in Indonesia.

Although the results of these two field trials were very encouraging, this vaccine was not evaluated for children less than 5 year of age. Therefore, with the sponsorship of WHO, the immune response and side effects study of Vi-CPS vaccine for children and infants were conducted in Indonesia. For safety consideration the study evaluation was conducted in 2 steps. The first study participants were the older children (1-10 year old) and adults and than proceed to infants 6-12 month old in the latter study.

The seroconversion rate of the Vi-CPS for children 110 year old and adults was $85.1 \%$ and $72.4 \%$, respectively. In infants of 6-12 months the seroconversion rate was $79 \%$. The incidence of side effects was very minimal. The incidence of side effects was lower in vaccine recipient group compared to control group, which received pneumococcal and meningococcal vaccines $\mathrm{A} \& \mathrm{C}$, another licensed polysaccharide vaccines.

The duration of protective efficacy of this vaccine has been reported to be at least 21 months and the vaccine can be given safely to infants as young as 6 month without significant side effects, however since the immune response duration of this vaccine is not known, the protective efficacy study of this vaccine need to be conducted.

The Vi-CPS vaccine has no booster effect. This is the reason why the conjugate version of this vaccine with aro/protein has been developed and the evaluation of this conjugate vaccine is under way elsewhere.

\section{Combination of Vi-CPS and Ty21a vaccines}

Both, the oral Ty21a and the parenteral Vi-CPS vaccine work on different mechanism of immunity. The Vi-CPS is thought to protect by inducing antibodies to Vi-antigen. Ty21a induces antibodies to attenuated $S$. typhi, but is thought to work primarily on cell mediated immunity. Ty21a does not contain Vi-antigen, thus these two vaccines induce protective immune responses against at least 2 different $S$. typhi antigens and probably work through different mechanism of immune responses. Thus immunizing individuals with both vaccines might induce additive or synergistic immune responses and lead to increased protective efficacy.

\section{References}

1. Simanjuntak $\mathrm{CH}$, Hoffman SL, Punjabi NH et al. (Indonesian). Epidemiologi demam tifoid di suatu daerah pedesaan di Paseh, Jawa Barat, Indonesian. Cermin Dunia Kedokteran 1987; 45: 16-8.

2. Simanjuntak, Paleologo FP, Punjabi NH et al. Oral immunization against typhoid fever in Indonesia with Ty2 la vaccine. Lancet 1992; 338: 1055-9. 
3. Simanjuntak $\mathrm{CH}$. Masaalah demam tifoid di Indonesia (Indonesian). Cermin Dunia Kedokteran 1990; 60: 31-4.

4. Depkes. Data survailans tahun 1994, 1995; 43

5. Wahdan MH, Serie C, Cerisier Y and Germanier R. A controlled field trial of live Salmonella typhi strain Ty21a oral vaccine against typhoid: three year results. J Infect Dis 1982; 145: 292-5.

6. Levine MM, Ferreccio C, Black RE, Germanier R and Chilean Typhoid Committee. Largescale field trial of Ty21a live oral typhoid vaccine in entericcoated coated capsule formu- lation. Lancet 1987; i: 1049-52.

7. Levine MM. Personal communication.

8. Klugman KP, Gilbertson IT, Koornhof HJ et al. Protective activity of Vi Capsular Polysaccharide Vaccine Against Typhoid Fever. Lancet 1987; XI(1): 1165-9.

9. Acharya IL, Lowe CU, Thapa R et al. Prevention of typhoid fever in Nepal with the Vi capsular Polysaccharide of Salmonella typhi. A preliminary report. $\mathrm{N}$ Engl J Med 1987; 317(18): 1101-4. 